Abstracta Iranicacta Iranica

Revue bibliographique pour le domaine irano-aryen

Volume 27 | 2006

Comptes rendus des publications de 2004

\title{
TārïH-e Čìn / History of China and Cathay. Y. Wang, ed., Tehran, PUI, 2000, 284 p., index.
}

\section{Rédaction}

\section{(2) OpenEdition}

1 Journals

\section{Édition électronique}

URL : http://journals.openedition.org/abstractairanica/6317

DOI : 10.4000/abstractairanica.6317

ISSN : 1961-960X

Éditeur :

CNRS (UMR 7528 Mondes iraniens et indiens), Éditions de l'IFRI

Édition imprimée

Date de publication : 15 mai 2006

ISSN : 0240-8910

\section{Référence électronique}

Rédaction, "Tārīh-e Ċiñ / History of China and Cathay. Y. Wang, ed., Tehran, PUI, 2000, 284 p., index. », Abstracta Iranica [En ligne], Volume 27 | 2006, document 290, mis en ligne le 02 janvier 2007, consulté le 25 septembre 2020. URL : http://journals.openedition.org/abstractairanica/6317 ; DOI : https:// doi.org/10.4000/abstractairanica.6317

Ce document a été généré automatiquement le 25 septembre 2020.

Tous droits réservés 


\section{TārīH-e Čìn / History of China and Cathay. Y. Wang, ed., Tehran, PUI, 2000, 284 p., index.}

\section{Rédaction}

1 As a part of the voluminous work of the universal history Jāmi al-TavārīH ("The Collection of Histories") by Rašìd al-Dīn Faḍl-Allāh Hamadānī (1247-1318), the famous Persian statesman and historian living in the Il-khan dynasty (1256-1353), the volume of The History of China and Cathay, compiled in 1304, contains a selected record of events covering a long history of China, from the earliest ancestor Pangu to the downfall of the Southern Song Dynasty (1127-1279), including 36 dynasties and 267 emperors and rulers in the history of China up to Rašìd al-Dīn's time. It is the first general history of China written by a foreign scholar from the Western Regions (Xiyu). What is of particular significance to the history of science is the "Introduction" to the History of China, in which Rašĩd al-Dīn told us about the activities of Chinese scholars living in Persia especially about the cooperation of the Chinese sage Qūminị (?) with the Persian

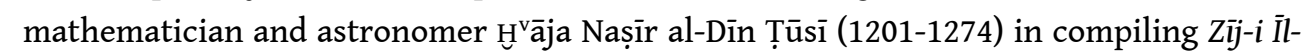
Hुānī ("The Astronomical Tables of Il-khan"). After that, Rašīd al-Dīn gave a description of some features of Chinese culture and made an appropriate evaluation on the characteristic of Chinese writing and the Chinese calendar system, the advantages of the Chinese characters that denote amounts in contracts and laws, the technique of Chinese wood block printing, the official tradition of the composition of history in China, etc. His work reflects the exact knowledge and highest achievements of a nonChinese scholar in the field of Chinese culture studies by that time, and provides us with valuable historical materials for the study of Sino-Iranian cultural communications and confluence in the 13th-14th centuries. 
INDEX

Thèmes : 10. Histoire des Sciences et des Techniques nompropre Tusi, Nasir al-Din Tusi

\section{AUTEURS}

\section{RÉDACTION}

Directeur de la revue et secrétariats (Paris et Téhéran) 